\title{
Organochlorine pesticide residues in human fat in the United Kingdom 1976-7
}

\author{
D C ABBOTT, G B COLLINS, R GOULDING， R A HOODLESS
}

\begin{abstract}
Between May 1976 and August 1977 samples of human body fat were taken during routine necropsies in the United Kingdom on 236 subjects aged over 5 years and four infants aged under 4 months. Comparison with results from earlier studies showed a further decline in residues of $\mathbf{p p}^{\prime}$-dichlorodiphenyltrichloroethane (pp'DDT) and dieldrin (HEOD) and increased amounts of hexachlorobenzene residues; concentrations of other compounds were similar to those observed in the studies carried out in 1963-4, 1965-7, and 1969-71. Comparison of the data with those from other countries showed that the concentrations of organochlorine pesticide residues and polychlorobiphenyls in human fat samples from residents of the United Kingdom remain among the lowest in Europe and, indeed, the world.
\end{abstract}

\section{Introduction}

Studies of the occurrence of trace amounts of organochlorine pesticides and similar compounds in human body tissues continue to attract attention in many countries. The national mean concentrations of these substances have been taken as offering a convenient and valid index of the average overall extent of exposure of the population. Each set of results is of value in itself, but repeated studies at intervals of some years allow trends in concentrations to be observed, which may be correlated with known or suspected changes in usage and availability of the

Laboratory of the Government Chemist, Department of Industry, London SE1 9NQ

D C ABBOTT, BSC, PHD, deputy director (customer services)

G B COLLINS, BSC, formerly principal scientific officer in charge, pesticide residues surveys

R A HOODLESS, BSC, PHD, principal scientific officer in charge, pesticide analysis research

Poisons Unit, New Cross Hospital, London SE14 5ER

R GOULDING, MD, FRCP, formerly director compounds concerned. The study reported here is the fourth in a series designed and carried out in similar ways, the earlier work $^{1-3}$ covering 1963-4, 1965-7, and 1969-71.

\section{Experimental methods and materials}

Between May 1976 and August 1977, 236 samples of human body fat were collected at necropsy from subjects over 5 years old during the course of routine examinations by pathologists throughout the United Kingdom. In addition, four similar samples from infants less than 4 months old were received. All specimens were placed in specially cleaned and prepared glass phials and stored at $-20^{\circ} \mathrm{C}$ until analysis. The samples were examined by the gas-liquid chromatographic procedure recommended for analysis of animal fats by the Committee for Analytical Methods of the Ministry of Agriculture, Fisheries, and Food. ${ }^{4}$ All extracts after clean-up were fractionally eluted from silica gel to separate polychlorobiphenyls, hexachlorobenzene, and most of the $p p^{\prime}-\mathrm{DDE}$ (a derivative of dichlorodiphenyltrichloroethane (DDT)) from the other residues. ${ }^{5}$ The semi-quantitative assessment of the concentration of polychlorobiphenyls was based on a comparison with Aroclor 1260. ${ }^{6}$ The identities of the major residues found were confirmed in some selected extracts by a range of chemical and physical means. ${ }^{6}$

\section{Results and discussion}

Table I shows the combined results for all samples obtained from subjects over 5 years old. For each residue the distribution of results among the samples was usually skew, and geometric means are possibly more meaningful than arithmetic means when comparison with other data is required; these were therefore included for the major residues.

Table II shows the results for the subjects over 5 years old subdivided according to sex, together with those from the earlier studies in this series. ${ }^{1-3}$ The only residue for which a pronounced reduction was apparent was $p p^{\prime}-\mathrm{DDT}$, and this probably reflects the restrictions on the use of DDT imposed in many countries, including the United Kingdom, over the past few years. The gradual reduction in total DDT since 1963 is almost entirely due to this decrease in $p p^{\prime}-\mathrm{DDT}$, the concentration of $p p^{\prime}-\mathrm{DDE}$ having remained fairly constant since the studies began. Perhaps not surprisingly, residual concentrations of $p p^{\prime}-\mathrm{DDE}$ have not yet been influenced by the decreased use of DDT, as its rate of elimination is low. ${ }^{78} \mathrm{~A}$ parallel decrease has been 
TABLE I-Residues of organochlorine compounds in human fat (mg/kg) in the United Kingdom, 1976-7. (Results obtained in 236 subjects over 5 years old)

\begin{tabular}{|c|c|c|c|c|c|c|c|c|c|c|c|}
\hline & & & Beta-HCH & $\begin{array}{l}\text { Total } \\
\text { HCH }\end{array}$ & $\begin{array}{c}\text { Heptachlor } \\
\text { epoxide }\end{array}$ & $\begin{array}{l}\text { Dieldrin } \\
\text { (HEOD) }\end{array}$ & $p p^{\prime}-\mathrm{DDE}$ & $p p^{\prime}-\mathrm{DDT}$ & $\begin{array}{l}\text { Total } \\
\text { DDT* }\end{array}$ & $\begin{array}{l}\text { Hexachloro- } \\
\text { benzene }\end{array}$ & PCB \\
\hline $\begin{array}{l}\text { Arithmetic mean } \\
\text { Ranget } \\
\text { Standard error of mean } \\
\text { Median value } \\
\text { Geometric mean } \\
95 \% \text { confidence limits for }\end{array}$ & $\begin{array}{cc}. & \because \\
\because & \because \\
\because & \because \\
\ddot{z} & \because \\
\text { geometric mean }\end{array}$ & $\begin{array}{l}\because \\
\because \\
\because \\
. .\end{array}$ & $\begin{array}{c}0 \cdot 31 \\
T-1 \cdot 2 \\
0 \cdot 01 \\
0 \cdot 29 \\
0 \cdot 24 \\
0 \cdot 22-0 \cdot 27\end{array}$ & $\begin{array}{c}0.33 \\
T-1 \cdot 2 \\
0.01 \\
0.31 \\
0 \cdot 27 \\
0.24-0.29\end{array}$ & $\begin{array}{c}0.03 \\
T-0.12\end{array}$ & $\begin{array}{c}0.11 \\
T-0.49 \\
0.01 \\
0.09 \\
0.09 \\
0.08-0 \cdot 10\end{array}$ & $\begin{array}{c}2 \cdot 1 \\
0.03-15 \\
0.12 \\
1.7 \\
1.5 \\
1 \cdot 3-1 \cdot 7\end{array}$ & $\begin{array}{c}0.21 \\
T-2 \cdot 4 \\
0.01 \\
0 \cdot 17 \\
0.15 \\
0 \cdot 14-0 \cdot 17\end{array}$ & $\begin{array}{l}2 \cdot 6 \\
0.04-17 \\
0.15 \\
2 \cdot 1 \\
1.9 \\
1 \cdot 6-2 \cdot 1\end{array}$ & $\begin{array}{c}0 \cdot 19 \\
0 \cdot 02-3 \cdot 2 \\
0 \cdot 01 \\
0 \cdot 15 \\
0 \cdot 15 \\
0 \cdot 14-0 \cdot 17\end{array}$ & $\begin{array}{l}0 \cdot 7 \\
T-10 \\
0.05 \\
0 \cdot 7 \\
0 \cdot 6 \\
0 \cdot 5-0.6\end{array}$ \\
\hline
\end{tabular}

"Total DDT was calculated by adding to the $p p^{\prime}-\mathrm{DDT}$ found as such the $p p^{\prime}-\mathrm{DDT}$ equivalent of the $p p^{\prime}-\mathrm{DDE}$ and $p p^{\prime}-\mathrm{TDE}$

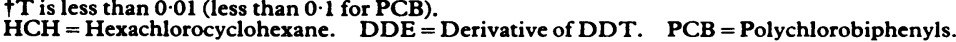

TABLE II-Distribution of residues of organochlorine compounds in fat of subjects over 5 years old during 1963-77 (mg/kg)

\begin{tabular}{|c|c|c|c|c|c|c|c|c|c|c|c|}
\hline & & & & \multicolumn{2}{|c|}{$1963-4$} & \multicolumn{2}{|c|}{$1965-7$} & \multicolumn{2}{|c|}{$1969-71$} & \multicolumn{2}{|c|}{$1976-7$} \\
\hline & & & & $\begin{array}{c}\text { Male } \\
(n=43)\end{array}$ & $\begin{array}{l}\text { Female } \\
(\mathrm{n}=23)\end{array}$ & $\begin{array}{c}\text { Male } \\
(\mathrm{n}=157)\end{array}$ & $\begin{array}{l}\text { Female } \\
(\mathbf{n}=91)\end{array}$ & $\begin{array}{c}\text { Male } \\
(n=116)\end{array}$ & $\begin{array}{l}\text { Female } \\
(n=85)\end{array}$ & $\begin{array}{c}\text { Male } \\
(\mathrm{n}=155)\end{array}$ & $\begin{array}{l}\text { Female } \\
(\mathbf{n}=81)\end{array}$ \\
\hline $\begin{array}{l}\text { HCWH: } \\
\text { Beta-HCH }\end{array}$ & Arithmetic mean & .. & $\ldots$ & & & 0.28 & $0 \cdot 28$ & $0 \cdot 27$ & 0.26 & $0 \cdot 30$ & 0.33 \\
\hline Total HCH & $\left\{\begin{array}{l}\text { Arithmetic mean } \\
\text { Geometric mean } \\
\text { Range* }\end{array}\right.$ & $\begin{array}{l}\cdots \\
\because\end{array}$ & $\begin{array}{l}\cdots \\
\because \\
\cdots\end{array}$ & $\begin{array}{l}0.43 \\
0.35 \\
\mathrm{~T}-1 \cdot 0\end{array}$ & $\begin{array}{l}0 \cdot 40 \\
0 \cdot 33 \\
T-1 \cdot 0\end{array}$ & $\begin{array}{c}0.31 \\
0.24 \\
0.01-1.9\end{array}$ & $\begin{array}{c}0.30 \\
0 \cdot 25 \\
0.04-0.81\end{array}$ & $\begin{array}{c}0.30 \\
0.24 \\
T-0.88\end{array}$ & $\begin{array}{c}0.28 \\
0.24 \\
0.03-0.61\end{array}$ & $\begin{array}{c}0.33 \\
0.26 \\
0.01-1 \cdot 2\end{array}$ & $\begin{array}{r}0.35 \\
0.29 \\
T-1 \cdot 1\end{array}$ \\
\hline Heptachlor epoxide & $\left\{\begin{array}{l}\text { Arithmetic mean } \\
\text { Range* }^{*}\end{array}\right.$ & 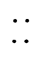 & $\because$ & & & $\begin{array}{r}0.045 \\
T-0.40\end{array}$ & $\begin{array}{c}0.032 \\
\mathrm{~T}=0.08\end{array}$ & $\begin{array}{r}0.027 \\
T-0.14\end{array}$ & $\begin{array}{c}0.024 \\
T-0.08\end{array}$ & $\begin{array}{c}0.03 \\
T-0.09\end{array}$ & $\begin{array}{l}0.03 \\
T-0.12\end{array}$ \\
\hline Dieldrin (HEOD) & $\left\{\begin{array}{l}\text { Arithmetic mean } \\
\text { Geometric mean } \\
\text { Range* }^{*}\end{array}\right.$ & $\begin{array}{l}. \\
\cdots\end{array}$ & $\begin{array}{l}. \\
\cdots\end{array}$ & $\begin{array}{c}0 \cdot 27 \\
0 \cdot 21 \\
T-0.9\end{array}$ & $\begin{array}{c}0 \cdot 23 \\
0 \cdot 21 \\
T-0 \cdot 5\end{array}$ & $\begin{array}{c}0 \cdot 23 \\
0 \cdot 18 \\
0 \cdot 01-1 \cdot 0\end{array}$ & $\begin{array}{l}0.18 \\
0.15 \\
T-0.50\end{array}$ & $\begin{array}{l}0.16 \\
0.12 \\
T-0.68\end{array}$ & $\begin{array}{l}0 \cdot 16 \\
0 \cdot 12 \\
0 \cdot 10-0.58\end{array}$ & $\begin{array}{l}0.11 \\
0.09 \\
T-0.46\end{array}$ & $\begin{array}{l}0.11 \\
0.08 \\
0.01-0.49\end{array}$ \\
\hline $\begin{array}{l}p p^{\prime}-\mathrm{DDE} \\
p p^{\prime}-\mathrm{DDT}\end{array}$ & $\begin{array}{l}\text { Arithmetic mean } \\
\text { Arithmetic mean }\end{array}$ & $\begin{array}{l}\cdots \\
\cdots\end{array}$ & $\begin{array}{l}\cdots \\
\cdots\end{array}$ & $\begin{array}{l}2 \cdot 2 \\
1 \cdot 2\end{array}$ & $\begin{array}{l}1.5 \\
1.0\end{array}$ & $\begin{array}{l}2 \cdot 2 \\
0 \cdot 83\end{array}$ & $\begin{array}{l}1.6 \\
0.68\end{array}$ & $\begin{array}{l}1.9 \\
0.54\end{array}$ & $\begin{array}{l}1 \cdot 6 \\
0.49\end{array}$ & $\begin{array}{l}2 \cdot 1 \\
0 \cdot 20\end{array}$ & $\begin{array}{l}2 \cdot 1 \\
0 \cdot 23\end{array}$ \\
\hline Total DDT & $\left\{\begin{array}{l}\text { Arithmetic mean } \\
\text { Geometric mean } \\
\text { Range ... }\end{array}\right.$ & $\begin{array}{l}\cdots \\
\cdots\end{array}$ & $\begin{array}{l}\ldots \\
\cdots\end{array}$ & $\begin{array}{c}3.7 \\
3.0 \\
0.4-8.5\end{array}$ & $\begin{array}{c}2 \cdot 7 \\
2 \cdot 2 \\
0 \cdot 2-8 \cdot 0\end{array}$ & $\begin{array}{l}3 \cdot 3 \\
2 \cdot 8 \\
0 \cdot 08-13\end{array}$ & $\begin{array}{l}2 \cdot 5 \\
2 \cdot 2 \\
0 \cdot 21-8 \cdot 1\end{array}$ & $\begin{array}{l}2 \cdot 7 \\
2 \cdot 1 \\
0 \cdot 08-9 \cdot 5\end{array}$ & $\begin{array}{l}2 \cdot 3 \\
1 \cdot 7 \\
0 \cdot 14-6 \cdot 7\end{array}$ & $\begin{array}{c}2 \cdot 6 \\
2 \cdot 0 \\
0 \cdot 13-12\end{array}$ & $\begin{array}{l}2.6 \\
1.6 \\
0.04-17\end{array}$ \\
\hline Hexachlorobenzene & $\left\{\begin{array}{l}\text { Arithmetic mean } \\
\text { Range }^{*}\end{array}\right.$ & . & 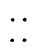 & & & & & $\begin{array}{l}0.05 \\
T-0.11\end{array}$ & $\begin{array}{c}0.05 \\
0.01-0.29\end{array}$ & $\begin{array}{c}0 \cdot 18 \\
0.02-0 \cdot 68\end{array}$ & $\begin{array}{c}0.22 \\
0.02-3 \cdot 2\end{array}$ \\
\hline PCB & $\left\{\begin{array}{l}\text { Arithmetic mean } \\
\text { Range }^{*}\end{array}\right.$ & $\therefore$ & $\therefore$ & & & & & All less & $\tan 1 \cdot 0^{+}$ & $\begin{array}{l}0 \cdot 8 \\
0 \cdot 1-10\end{array}$ & $\begin{array}{l}0.6 \\
T-1 \cdot 5\end{array}$ \\
\hline
\end{tabular}

${ }^{*} \mathrm{~T}$ is less than 0.01 (less than 0.1 for PCB).

$+\mathrm{PCB}$ was not measured in all cases.

observed since 1966 in the ratio of $p p^{\prime}-\mathrm{DDT}$ to total DDT in the average diet in the United Kingdom. ${ }^{9}$

The slight decrease in dieldrin concentrations probably represents a real effect, as a slow but continuous downward trend is apparent in all studies; this again is probably associated with the successive withdrawals of clearance for the various uses of this pesticide and of aldrin, of which HEOD (dieldrin) is a metabolite. The concentration of hexachlorobenzene found in 1976-7 was higher than that found in the previous study. ${ }^{3}$ Although this is partly a consequence of better analytical recovery of this compound, this factor alone would account for not more than $30 \%$ of the observed increase. The source of these residues is not attributable with any certainty. Hexachlorobenzene is not cleared for use as an agricultural chemical in the United Kingdom. It occurs as an impurity in several substances, however, and is among the waste byproducts of industrial chlorination processes.

Concentrations of polychlorobiphenyls also showed a slight overall increase. Although in the previous study polychlorobiphenyls were measured quantitatively only in those few samples showing the highest concentrations, it was concluded that, in those samples, the concentrations did not exceed an estimated $1 \mathrm{mg} / \mathrm{kg}$. In the present study estimates made on the same basis, though showing a mean value below

TABLE III-Arithmetic means of residues of organochlorine compounds in human fat by geographical location of subjects 1976-7 ( $\mathrm{mg} / \mathrm{kg})$

\begin{tabular}{|c|c|c|c|c|c|c|c|c|}
\hline & \multicolumn{2}{|c|}{$\begin{array}{l}\text { Southern } \\
\text { England* }\end{array}$} & \multicolumn{2}{|c|}{$\begin{array}{l}\text { Northern } \\
\text { England } \\
\text { and Wales } \dagger\end{array}$} & \multicolumn{2}{|c|}{ Scotland $\ddagger$} & \multicolumn{2}{|c|}{$\begin{array}{l}\text { Northern } \\
\text { Ireland } \S\end{array}$} \\
\hline & $\begin{array}{c}\text { Male } \\
(\mathrm{n}=74\end{array}$ & Female & $\begin{array}{l}\text { Male } \\
(n=51)\end{array}$ & $\begin{array}{l}\text { Female } \\
(n=26)\end{array}$ & $\begin{array}{l}\text { Male } \\
(\mathrm{n}=22\end{array}$ & $\begin{array}{l}\text { Female } \\
(\mathbf{n}=\mathbf{9})\end{array}$ & $\begin{array}{c}\text { Male } \\
(\mathrm{n}=8)\end{array}$ & $\begin{array}{l}\text { Female } \\
(\mathbf{n}=3)\end{array}$ \\
\hline 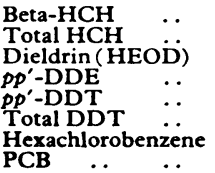 & $\begin{array}{l}0.29 \\
0.31 \\
0 \cdot 11 \\
2.3 \\
0 \cdot 20 \\
2 \cdot 8 \\
\text { e } 0.18 \\
0.7\end{array}$ & $\begin{array}{l}0 \cdot 34 \\
0 \cdot 37 \\
0 \cdot 11 \\
2 \cdot 7 \\
0 \cdot 27 \\
3 \cdot 3 \\
0 \cdot 27 \\
0 \cdot 7\end{array}$ & $\begin{array}{l}0.33 \\
0 \cdot 36 \\
0 \cdot 13 \\
2 \cdot 0 \\
0 \cdot 21 \\
2 \cdot 5 \\
0 \cdot 17 \\
0.7\end{array}$ & $\begin{array}{l}0.33 \\
0.36 \\
0.13 \\
1.5 \\
0.21 \\
1.9 \\
0.17 \\
0.5\end{array}$ & $\begin{array}{l}0.21 \\
0.23 \\
0.09 \\
1.7 \\
0.16 \\
2.1 \\
0.13 \\
0.6\end{array}$ & $\begin{array}{l}0.25 \\
0.27 \\
0.08 \\
1.6 \\
0.15 \\
2 \cdot 0 \\
0.17 \\
0.6\end{array}$ & $\begin{array}{l}0 \cdot 49 \\
0.52 \\
0 \cdot 10 \\
2 \cdot 9 \\
0 \cdot 29 \\
3 \cdot 6 \\
0 \cdot 26 \\
2 \cdot 0\end{array}$ & $\begin{array}{l}0.31 \\
0.33 \\
0.08 \\
1.2 \\
0.11 \\
1.5 \\
0.19 \\
0.4\end{array}$ \\
\hline
\end{tabular}

* Aylesbury, Bishop's Stortford, East Grinstead, London, Reading, St Austell, Salisbury, Sevenoaks, Winchester.

tLeeds, Walsall, Warwick, Wolverhampton, Bangor, Cardiff.

Aberdeen, Dundee, Edinburgh.
TABLE IV-Distribution of residues of organochlorine compounds in human fat by age, concentration, and sex (1976-7). Results are given as percentages

\begin{tabular}{|c|c|c|c|c|c|c|}
\hline \multirow{3}{*}{$\begin{array}{c}\text { Residue } \\
\text { range } \\
(\mathrm{mg} / \mathbf{k g})\end{array}$} & \multicolumn{6}{|c|}{ Age group (years) } \\
\hline & \multicolumn{2}{|c|}{$5-40$} & \multicolumn{2}{|c|}{$41-60$} & \multicolumn{2}{|c|}{ Over 60} \\
\hline & $\begin{array}{c}\text { Male } \\
(\mathrm{n}=26)\end{array}$ & $\begin{array}{c}\text { Female } \\
(n=8)\end{array}$ & $\begin{array}{c}\text { Male } \\
(n=49)\end{array}$ & $\begin{array}{l}\text { Female } \\
(n=15)\end{array}$ & $\begin{array}{c}\text { Male } \\
(\mathbf{n}=\mathbf{8 0})\end{array}$ & $\begin{array}{l}\text { Female } \\
(n=58)\end{array}$ \\
\hline \multicolumn{7}{|c|}{ Total $\mathrm{HCH}$} \\
\hline $\begin{array}{r}0-0 \cdot 10 \\
0 \cdot 11-0 \cdot 20 \\
0 \cdot 21-0 \cdot 30 \\
0 \cdot 31-0.40 \\
\text { Over } 0.40\end{array}$ & $\begin{array}{r}35 \\
23 \\
15 \\
8 \\
19\end{array}$ & $\begin{array}{l}12 \\
25 \\
37 \\
13 \\
13\end{array}$ & $\begin{array}{l}12 \\
12 \\
27 \\
31 \\
18\end{array}$ & $\begin{array}{r}20 \\
27 \\
20 \\
26 \\
7\end{array}$ & $\begin{array}{l}1 \\
25 \\
11 \\
15 \\
48\end{array}$ & $\begin{array}{l}12 \\
14 \\
16 \\
19 \\
39\end{array}$ \\
\hline \multicolumn{7}{|c|}{ Dieldrin $(H E O D)$} \\
\hline $\begin{array}{r}0-0.10 \\
0.11-0.20 \\
0 \cdot 21-0.30 \\
0.31-0.40 \\
\text { Over } 0.40\end{array}$ & $\begin{array}{r}73 \\
19 \\
8\end{array}$ & $\begin{array}{l}87 \\
13\end{array}$ & $\begin{array}{r}47 \\
47 \\
2 \\
4 \\
\\
p^{\prime}-D D E\end{array}$ & $\begin{array}{r}66 \\
27 \\
7\end{array}$ & $\begin{array}{r}44 \\
41 \\
11 \\
3 \\
1\end{array}$ & $\begin{array}{r}52 \\
33 \\
7 \\
5 \\
3\end{array}$ \\
\hline $\begin{array}{r}0-1 \cdot 0 \\
1 \cdot 1-2 \cdot 0 \\
2 \cdot 1-3 \cdot 0 \\
3 \cdot 1-4 \cdot 0 \\
4 \cdot 1-5 \cdot 0 \\
\text { Over } 5 \cdot 0\end{array}$ & $\begin{array}{r}46 \\
27 \\
23 \\
4\end{array}$ & $\begin{array}{l}63 \\
25 \\
12\end{array}$ & $\begin{array}{c}15 \\
51 \\
10 \\
10 \\
10 \\
4 \\
p^{\prime}-D D T\end{array}$ & $\begin{array}{l}40 \\
14 \\
20 \\
13 \\
13\end{array}$ & $\begin{array}{r}14 \\
25 \\
31 \\
19 \\
5 \\
6\end{array}$ & $\begin{array}{r}39 \\
21 \\
12 \\
12 \\
9 \\
7\end{array}$ \\
\hline $\begin{array}{l}0-0 \cdot 20 \\
0.21-0.40 \\
0.41-0.60 \\
0.61-0.80 \\
0 \cdot 81-1 \cdot 0 \\
\text { Over } 1.0\end{array}$ & $\begin{array}{l}81 \\
19\end{array}$ & $\begin{array}{l}75 \\
25\end{array}$ & $\begin{array}{r}61 \\
35 \\
2 \\
2\end{array}$ & $\begin{array}{r}67 \\
13 \\
13 \\
7\end{array}$ & $\begin{array}{r}44 \\
41 \\
14 \\
1\end{array}$ & $\begin{array}{r}57 \\
30 \\
5 \\
3 \\
3 \\
2\end{array}$ \\
\hline $\begin{array}{r}0-1 \cdot 0 \\
1 \cdot 1-2 \cdot 0 \\
2 \cdot 1-3 \cdot 0 \\
3 \cdot 1-4 \cdot 0 \\
4 \cdot 1-5 \cdot 0 \\
\text { Over } 5 \cdot 0\end{array}$ & $\begin{array}{r}38 \\
31 \\
15 \\
12 \\
4\end{array}$ & $\begin{array}{l}50 \\
25 \\
13 \\
12\end{array}$ & $\begin{array}{r}15 \\
39 \\
16 \\
12 \\
8 \\
10\end{array}$ & $\begin{array}{r}20 \\
34 \\
7 \\
13 \\
13 \\
13\end{array}$ & $\begin{array}{l}13 \\
19 \\
26 \\
19 \\
12 \\
11\end{array}$ & $\begin{array}{r}35 \\
17 \\
17 \\
7 \\
10 \\
14\end{array}$ \\
\hline \multicolumn{7}{|c|}{ Hexachlorobenzene } \\
\hline $\begin{array}{r}0-0.10 \\
0.11-0.20 \\
0.21-0.30 \\
0.31-0.40 \\
\text { Over } 0.40\end{array}$ & $\begin{array}{r}38 \\
35 \\
23 \\
4\end{array}$ & $\begin{array}{l}37 \\
37 \\
13 \\
13\end{array}$ & $\begin{array}{r}23 \\
51 \\
20 \\
2 \\
4 \\
P C B\end{array}$ & $\begin{array}{r}7 \\
47 \\
33 \\
13\end{array}$ & $\begin{array}{r}19 \\
40 \\
21 \\
15 \\
5\end{array}$ & $\begin{array}{r}22 \\
35 \\
26 \\
12 \\
5\end{array}$ \\
\hline \multicolumn{7}{|c|}{$P C B$} \\
\hline $\begin{array}{r}0-0.2 \\
0.3-0.4 \\
0.5-0.6 \\
0.7-0.8 \\
0.9-1.0 \\
\text { Over } 1.0\end{array}$ & $\begin{array}{r}4 \\
23 \\
19 \\
35 \\
11 \\
8\end{array}$ & $\begin{array}{l}38 \\
13 \\
13 \\
12 \\
12 \\
12\end{array}$ & $\begin{array}{r}4 \\
14 \\
17 \\
20 \\
25 \\
20\end{array}$ & $\begin{array}{l}20 \\
20 \\
27 \\
13 \\
20\end{array}$ & $\begin{array}{l}3 \\
11 \\
15 \\
25 \\
21 \\
25\end{array}$ & $\begin{array}{r}10 \\
15 \\
28 \\
9 \\
14 \\
24\end{array}$ \\
\hline
\end{tabular}


$1 \mathrm{mg} / \mathrm{kg}$, exceeded this figure in about $16 \%$ of the samples and, apart from the unusually high value of $10 \mathrm{mg} / \mathrm{kg}$ found in one sample, reached a maximum of $1.6 \mathrm{mg} / \mathrm{kg}$. Similar increases have been observed in Norway ${ }^{10}$ and Finland, ${ }^{11}$ while a possible slow increase in concentrations of polychlorobiphenyls in human milk has been reported in Sweden. ${ }^{12}$ For these compounds, as with $p p^{\prime}-D D E$, elimination from fat deposits is probably slow, so that it may take some years before the reduced scale of manufacture and use is reflected in a downward turn in concentrations in human fat.

Table III shows the association of concentrations with geographical location. For this purpose the United Kingdom was divided into four areas: England south of a line drawn from the Bristol Channel to the Wash; England north of this line together with Wales; Scotland; and Northern Ireland. Differences according to sex in concentrations of beta-hexachlorocyclohexane (beta-HCH), total $\mathrm{HCH}, p p^{\prime}-\mathrm{DDE}$, and total DDT were greatest in samples from Northern Ireland, where the mean concentration in male subjects was higher than that in male subjects from the other areas, although this was not so for the female subjects. Far fewer samples were obtained from Northern Ireland than $p p^{\prime}-\mathrm{DDE}$ and $\mathrm{HCH}$ isomers have remained similar to those reported in the 1969-71 survey. Residue concentrations of hexachlorobenzene are now somewhat higher than those previously reported.

Results of similar surveys carried out in member States of the European Community up to 1972 were reviewed by Gatti, ${ }^{15}$ while a worldwide list summarising results published up to 1974 was compiled by Wassermann et al. ${ }^{16}$ Table VI compares results obtained from the present survey with those recently reported elsewhere. These comparisons show that the amounts of organochlorine pesticide residues and polychlorobiphenyls in human fat samples from residents of the United Kingdom remain among the lowest in Europe and, indeed, the world.

We should like to thank the pathologists throughout the country who made this work possible by providing suitable samples, and the members of staff of the Laboratory of the Government Chemist who

TABLE V-Residues of organochlorine compounds in fat of four infants under 4 months old, 1976-7 (mg/kg)

\begin{tabular}{ccccccccc}
\hline Age & Beta-HCH & $\begin{array}{c}\text { Total } \\
\text { HCH }\end{array}$ & $\begin{array}{c}\text { Dieldrin } \\
\text { (HEOD) }\end{array}$ & $p p^{\prime}$-DDE & $p p^{\prime}$-DDT & $\begin{array}{c}\text { Total } \\
\text { DDT }\end{array}$ & $\begin{array}{c}\text { Hexachloro- } \\
\text { benzene }\end{array}$ & PCB \\
\hline Newborn & 0.07 & 0.10 & 0.03 & 0.54 & 0.04 & 0.68 & 0.04 & 0.1 \\
2 months & 0.10 & 0.11 & 0.02 & 0.50 & 0.01 & 0.60 & 0.05 & 0.2 \\
3 months & 0.03 & 0.03 & 0.09 & 0.95 & 0.14 & 1.06 & 0.13 & 0.5 \\
3 months & 0.15 & 0.17 & 0.09 & 0.92 & 0.14 & \\
\hline
\end{tabular}

TABLE VI-Residues of organochlorine compounds in human fat in various countries

\begin{tabular}{|c|c|c|c|c|c|c|c|c|c|c|c|}
\hline \multirow{2}{*}{ Country } & & & \multirow{2}{*}{ Period } & \multirow{2}{*}{$\begin{array}{c}\text { No of } \\
\text { samples }\end{array}$} & \multicolumn{6}{|c|}{ Mean residues $(\mathrm{mg} / \mathbf{k g})$} & \multirow{2}{*}{ Reference } \\
\hline & & & & & $\begin{array}{l}\text { Total } \\
\text { HCH }\end{array}$ & $\begin{array}{l}\text { Dieldrin } \\
\text { (HEOD) }\end{array}$ & $p p^{\prime}-D D E$ & $p p^{\prime}-\mathrm{DDT}$ & $\begin{array}{c}\text { Hexachloro- } \\
\text { benzene }\end{array}$ & PCB & \\
\hline 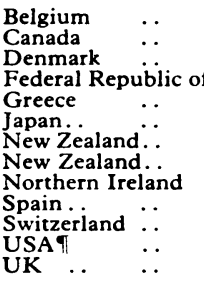 & $\begin{array}{l}\because \\
\because \\
\text { f G̈erma } \\
\cdots \\
\because \\
\cdots \\
\cdots \\
\cdots \\
\cdots \\
\therefore\end{array}$ & $\begin{array}{l}\cdots \\
\cdots \\
a \\
\cdots \\
\cdots \\
\cdots \\
\cdots \\
\cdots \\
\cdots \\
\cdots\end{array}$ & $\begin{array}{c}1975 \\
1972 \\
1972-3 \\
\\
1974 \\
1973 \\
1973-4 \\
1975 \\
1977 \\
1971-2 \\
1973-4 \\
1976-7\end{array}$ & $\begin{array}{r}60 \\
168 \\
78 \\
282 \\
50 \\
30 \\
51 \\
21 \\
11 \\
40 \\
12 \\
898 \\
236\end{array}$ & $\begin{array}{l}0.76^{*} \\
0.065 \dagger \\
0.99 \dagger \ddagger \\
0.98 \S \\
2.36 \\
0.49 \dagger \\
\\
0.45 \\
0.062 \dagger \\
0.90^{*} \\
0.21 * \\
0.33\end{array}$ & $\begin{array}{l}0 \cdot 26 \\
0 \cdot 069 \\
0 \cdot 12 \\
0 \cdot 14 \ddagger \\
0 \cdot 23 \\
0 \cdot 21 \\
0 \cdot 10 \\
0 \cdot 150 \\
0 \cdot 29 \\
0 \cdot 15 \\
0 \cdot 11\end{array}$ & $\begin{array}{l}6 \cdot 5 \\
2 \cdot 095 \\
3 \cdot 7 \\
4 \cdot 4 \\
7 \cdot 86 \\
2 \cdot 91 \\
5 \cdot 64 \\
4 \cdot 4 \\
1 \cdot 60 \\
2 \cdot 268 \\
3 \cdot 8 \\
4 \cdot 1 \dagger \\
2 \cdot 1\end{array}$ & $\begin{array}{l}1.52 \\
0.439 \\
0.6 \dagger \\
1.1 \\
1.99 \\
0.68 \\
0.70 \\
0.46 \\
0.34 \\
1.781 \\
1.6 \\
0.21\end{array}$ & $\begin{array}{l}1.36 \\
0.062 \\
5 \cdot 6 \\
3.84 \\
0.31 \\
0.15 \\
1.9\end{array}$ & $\begin{array}{l}0.907 \\
3.8 \\
8.3 \\
\\
1.04 \\
0.82 \\
0.35\end{array}$ & $\begin{array}{c}17 \\
18 \\
19 \\
20 \\
21 \\
22 \\
23 \\
24 \\
13 \\
25 \\
26 \\
27 \\
\text { Present paper }\end{array}$ \\
\hline
\end{tabular}

*Present as beta-HCH. †Calculated from authors' data. \$Based on 50 samples. §Present as lindane (gamma-HCH). !Based on 35 samples. TExpressed as geometric means.

from the other areas, however, although these findings are in general agreement with the observations of Harper et $\mathrm{l}^{13}$ regarding concentrations of total $\mathrm{HCH}$. It has been suggested that this difference between Northern Ireland and other areas is due to a higher dietary intake of $\mathrm{HCH}$, mainly from dairy products, as higher concentrations of $\mathrm{HCH}$ isomers have been observed ${ }^{14}$ in dairy products in Northern Ireland compared with the rest of the United Kingdom. The mean concentrations of beta-HCH and total $\mathrm{HCH}$ in samples from Scotland were lower than those in samples from the other areas.

Table IV gives the distributions of the results for each compound by age, sex, and concentration. Fewer results fell in the higher ranges in the subjects aged 5-40 years than in the older subjects; but there was little difference between those aged 41-60 years and those aged over 60 years. The distribution of concentrations of polychlorobiphenyls was more even than the distributions of pesticide concentrations, almost all of which were skew with most results in the lower ranges. The exception was the total $\mathrm{HCH}$ residue in the group aged over 60.

Table $\mathrm{V}$ gives the results of the analyses of samples from infants under 4 months old, but these were too few to support any realistic conclusions. They do, however, serve to confirm earlier findings that such residues occur in newly born infants.

\section{Conclusions}

The previously observed decline in residue concentrations of $p p^{\prime}$-DDT and dieldrin has continued, while concentrations of carried out the analysis of the samples. Thanks are also due to Miss Joan Vernon for the statistical analyses of the results. This report is made by permission of the Government Chemist (Department of Industry), the Department of Health and Social Security, and the Ministry of Agriculture, Fisheries, and Food.

\section{References}

${ }^{1}$ Egan H, Goulding R, Roburn J, Tatton JO'G. Organochlorine pesticide residues in human fat and human milk. Br Med F 1965;ii:66-9.

2 Abbott DC, Goulding R, Tatton JO'G. Organochlorine pesticide residues in human fat in Great Britain. Br Med $\mathcal{7} 1968$;ii:146-9.

s Abbott DC, Collins GB, Goulding R. Organochlorine pesticide residues in human fat in the United Kingdom 1969-71. Br Med 7 1972;ii:553-6.

4 Panel on Determination of Organochlorine Pesticides in Foodstuffs of Animal Origin. Report. Determination of residues of organochlorine pesticides in animal fats and eggs. Analyst 1979;104:425-33.

${ }^{5}$ Holden AV, Marsden K. Single-stage clean-up of animal tissue extracts for organochlorine residue analysis. $\mathcal{f}$ Chromatogr 1969;44:481-92.

- Department of Industry. Report of the Government Chemist, 1979. London: HMSO, 1980:96-103.

7 Morgan DP, Roan CC. Absorption, storage and metabolic conversion of ingested DDT and DDT metabolites in man. Arch Environ Health $1971 ; 22: 301-8$.

${ }^{8}$ Roan C, Morgan D, Paschal EH. Urinary excretion of DDA following ingestion of DDT and DDT metabolites in man. Arch Environ Health $1971 ; 22: 309-15$.

- Department of Industry. Report of the Government Chemist, 1977. London: HMSO, 1978:19-27. 
${ }^{10}$ Brevik EM, Bjerk JE. Organochlorine compounds in Norwegian human fat and milk. Acta Pharmacol Toxicol 1978;43:59-63.

11 Hattula ML, Ikkala J, Isomäki M, Määttä K, Arstila AU. Chlorinated hydrocarbon residues (PCB and DDT) in human liver, adipose tissue and brain in Finland. Acta Pharmacol Toxicol 1976;39:545-54.

12 Westöö G, Norën K. Organochlorine contaminants in human milk, Stockholm, 1967-1977. Ambio 1978;7:62-4.

13 Harper DB, Smith RV, Gotto DM. BHC residues of domestic origin: a significant factor in pollution of freshwater in Northern Ireland. Environmental Pollution 1977;12:223-33.

14 Harper DB, McAnally RJ. Seasonal fluctuations in the concentration of BHC residues in butter. Pesticide Science 1977;8:35-42.

15 Gatti GL. Pesticide residues in human fat and human milk in the nine member states of the European Community (1969-1973). In: European colloquium on problems raised by the contamination of man and his environment by persistent pesticides and organo-halogenated compounds. EUR 5196. Luxembourg: Commission of the European Communities, 1975: 383-424.

16 Wassermann M, Tomatis L, Wassermann D. Storage map of organochlorine compounds in humans. In: Berlin A, Engel R, Smeets J, eds. Recent advances in the assessment of the health effects of environmental pollution: proceedings of an international symposium. EUR 5360. Vol II. Luxembourg: Commission of the European Communities, 1975:105366.

17 Dejonckheere W, Steurbaut W, Verstraeten R, Kips RH. Residues of organochlorine pesticides in human fat in Belgium. Mededelingen van de Faculteit Landbouwwetenschappen Rijksuniversiteit Gent 1977;42: $1839-47$.

${ }^{18}$ Mes J, Campbell DS, Robinson RN, Davies DJA. Polychlorinated biphenyl and organochlorine pesticide residues in adipose tissue of Canadians. Bull Environ Contam Toxicol 1977;17:196-203.

19 Kraul I, Karlog O. Persistent organochlorinated compounds in human organs collected in Denmark 1972-73. Acta Pharmacol Toxicol 1976;38: $38-48$.

20 Schulte E, Acker L. Zur Kontamination des Menschen mit Chlorkohlenwasserstoffen insbesondere durch PCB. In: European colloquium on problems raised by the contamination of man and his environment by persistent pesticides and organo-halogenated compounds. EUR 5196. Luxem- bourg: Commission of the European Communities, 1975:435-40.

21 Panetsos A, Psomas J, Kilikidis S. Chlorinated pesticides content of human fat in Greece. Iatriki $1975 ; 28: 460-4$.

${ }^{22}$ Fukano S, Doguchi M. PCT, PCB and pesticide residues in human fat and blood. Bull Environ Contam Toxicol 1977;17:613-7.

${ }^{23}$ Solly SRB, Shanks V. Polychlorinated biphenyls and organochlorine pesticides in human fat in New Zealand. New Zealand fournal of Science $1974 ; 17: 535-44$.

24 Zobel MGR. Analysis of polychlorinated biphenyl, DDE, and DDT in human fat. New Zealand fournal of Science 1975;18:627-33.

${ }^{25}$ Herrera Marteache A, Polo Villar LM, Jodral Villarejo M, Polo Villar G, Mallol J, Pozo Lora R. Residuos de plaguicidas organoclorados en grasa humana en España. Revista de Sanidad e Higiene Pública 1978;52: 1125-44.

${ }^{26}$ Zimmerli B, Marek B. Die Belastung der schweizerischen Bevölkerung mit Pestiziden. Mitteilungen aus dem Gebiet der Lebensmitteluntersuchung und Hygiene 1973;64:459-79.

27 Kutz F, Strassman S, Yobs A. Survey of pesticide residues and their metabolites in the general population of the United States. In : Berlin A, Wolff AH, Hasegawa $\mathrm{Y}$, eds. The use of biological specimens for the assessment of human exposure to environmental pollutants: proceedings of the international workshop at Luxembourg, 18-22 April 1977. EUR 5824 EN. Brussels, Luxembourg: Commission of the European Communities, 1979:267-74.

(Accepted 20 August 1981)

\section{OF INOCULATION.}

ThоU Gн no difeafe, after it is formed, baffles the powers of medicine more effectually than the fmall-pox, yet more may be done beforehand to render this difeafe favourable than any one we know, as almoft all the danger from it may be prevented by inoculation. This falutary invention has been known in Europe above half a century; but, like moft other ufeful difcoveries, it has, till of late, made but flow progrefs. It muft however be acknowledged, to the honour of this country, that inoculation has met with a more favourable reception here, than among any of our neighbours. It is ftill however far from being general, which we have reafon to fear will be the cafe, as long as the practice continues in the hands of the Faculty.

No difcovery can be of general utility, while the practice of it is kept in the hands of a few. Had the inoculation of the fmall-pox been introduced as a falhion, and not as a medical difcovery, or had it been practiced by the fame kind of operators here, as it is in thofe countries from whence we learned it, it had long ago been univerfal. The fears, jealoufies, the prejudices, and the oppofite interefts of the Faculty, are, and ever will be, the moft effectual obftacles to the progrefs of any falutary difcovery. Hence, it is that the practice of inoculation never became, in any meafure, general, even in England, till taken up by men not bred to phyfic. Thefe have not only rendered the practice more extenfive, but likewife more fafe, and, by acting under lefs reftraint than the regular practitioners, have taught them that the patient's greateft danger arofe, not from the want of care, but from the excefs of it.

MEDICINE.- The meafles being an inflammatory difeafe, without any critical difcharge of matter, as in the fmall-pox, bleeding is commonly neceffary, efpecially when the fever runs high, with difficulty of breathing, and great oppreffion of the breaft. But if the difeafe be of a mild kind, bleeding may be omitted.

BATHING the feet and legs frequently in luke-warm water both tends to abate the violence of the fever, and to promote the eruption.

THE patient is often greatly relieved by vomiting. When there is a tendency this way, it ought to be promoted by drinking lukewarm water, or weak camomile-tea.

WHEN the cough is very troublefome, with drynefs of the throat, and difficulty of breathing, the patient may hold his head over the fteam of warm water, and draw the fteam into his lungs.

HE may likewife lick a little fperma ceti and fugar-candy pounded together; or take now and then a fpoonful of the oil of fweet almonds, with fugar-candy diffolved in it. Thefe will foften the throat, and relieve the tickling cough.

IF at the turn of the difeafe the fever affumes new vigour, and there appears great danger of fuffocation, the patient muft be bled according to his ftrength, and bliftering-plafters applied, with a view to prevent the load from being thrown on the lungs, where if an inflammation fhould fix itfelf, the patient's life will be in imminent danger.

\section{OF THE ERYSIPELAS, OR ST. ANTHONY'S FIRE.}

THIS difeafe, which in fome parts of Britain is called the rofe, attacks perfons at any period of life, but is moft common between the age of thirty and forty. Perfons of a fanguine or plethoric habit are moft liable to it. It often attacks young people, and pregnant women; and fuch as have once been affiicted with it are very liable to have it again. Sometimes it is a primary difeafe, and at other times only a fymptom of fome other malady. Every part of the body is liable to be attacked by an eryfipelas, but it moft frequently feizes the legs or face, efpecially the latter. It is moft common in autumn, or when hot weather is fucceeded by cold and wet.

SYMPTOMS.- The eryfipelas attacks with fhivering, thirft, lofs of ftrength, pain in the head and back, heat, reftleffnefs, and a quick pulfe; to which may be added vomiting, and fometimes a delirium. On the fecond, third, or fourth day, the part fwells, becomes red, and fmall puftules appear; at which time the fever generally abates.

WHEN the eryfipelas feizes the foot, the parts contiguous fwell, the $\mathrm{fkin}$ (hines; and, if the pain be violent, it will afcend to the leg, and will not bear to be touched.

WHEN it attacks the face, it fwells, appears red, and the $\mathrm{fkin}$ is covered with fmall puftules filled with clear water. One or both eyes are generally clofed with the fwelling; and there is a difficulty of breathing. If the mouth and noftrils be very dry, and the patient drowfy, there is reafon to fufpect an inflammation of the brain.

IF the eryfipelas affects the breaft, it fwells and becomes exceedingly hard, with great pain, and is apt to fuppurate. There is a violent pain in the arm-pit on the fide affected, where an abfcefs is often formed.

(Buchan's Domestic Medicine, 1786.) 